\title{
Truck Art in Retrospect: The Ascension of Religious, Political and Cultural Visuals
}

\author{
Fatima Zahra* \\ School of the Arts, Universiti Sains Malaysia, 11800 USM Penang, Malaysia. \\ *Correspondence: zahrasiddiqi13@gmail.com (Fatima Zahra, School of the Arts, Universiti Sains Malaysia, 11800 USM \\ Penang, Malaysia).
}

\begin{abstract}
Truck art has a long and illustrious tradition in South Asia. It is, above all, one of Pakistan's most popular and globally recognized art forms. The visual representation of the cultures of Pakistan's four regions is the cause for this art form's appeal. As a result, truck art has evolved into a means of expressing many cultural ideas via the appealing quality of its images. Such images emphasis the significance of the location or place from where the vehicle comes. Furthermore, the truck's graphics are not only appealing but also effective communicators. It's a qualitative study based on a rhetorical analysis, with the goal of understanding the culturally impacted images displayed on trucks. The study of the chosen truck images is based on topic categories that investigate various cultural connections of visuals. According to the findings, these truck images are rhetorical visuals that may interact with viewers. It delivers more strong information in the form of images and displays greater aesthetical beauty that draws the audience as a cultural representative of the region or location. This study, on the other hand, uses exemplification to show that vehicle pictures have a larger impact on the audience and convey ideas more successfully by beautifying aesthetical, religious, or cultural themes. As consequence of such visual interpretations, one may become a detective who investigates cultural concepts, values, and traditions.
\end{abstract}

Keywords: Truck art, Retrospect, South Asian art, Ascension, Religious visuals and Cultural visuals.

\section{INTRODUCTION:}

Pakistani culture has been affected by Central Asia, South Asia, and Western Asia, among other places. There are about fifteen major ethnic groups in Pakistan, each with its own unique characteristics, historical lineages, customs, clothing, cuisine, and music. From the Indus Valley to Africa and Tibet, Punjabis, Sindhis, Hazaras, Makranis, and Baltis, Baloch, Pashtuns, and Kashmiris come from all over the globe. Apart from historical ethnic considerations, Islam has had a significant religious impact on Pakistani culture since its arrival in the region in $700 \mathrm{AD}$.

Pakistani culture has always included art and craft. These works of art are available in a variety of styles, materials, and aesthetics. Arabic calligraphy is one of the most significant skills in many local buildings and places, such as copper work, paintings, and carved wood. Sindh and Multan are well-known for their distinctive blue ceramics. Another kind of indigenous art is naqashi, or camel-skin lamp art, as well as colorful Mughal tile work. Pakistani truck art, on the other hand, is a globally recognized piece of art. In the first section, truck art is discussed in the context of the various influences on this art form; in the second section, truck art is discussed in the context of the various influences on this art form; and in the third section, truck art is discussed in the context of the various influences on this art form. Examine how the Indo-Pak subcontinent has impacted the 
design and themes of Pakistani trucks (Elias, 2003a). The second section, on the other hand, examines the fundamental characteristics of truck art that have been discovered through previous research, as well as the focus of previous investigations, the techniques used, and the reasons for this study's focus on a specific segment of this ubiquitous art form.

Despite the fact that various academics have defined truck art in different ways, this section will explain how and why researchers use words such as arena of competition, popular culture, moving solicits and canvasses, moving images, and diesel wings to characterize this complicated art form (Elias, 2003b).

\section{Historical importance of Vehicular Art or "Truck Art"}

Vehicle decoration, such as carts, chariots, and carriages, has been used from ancient times, according to excavation records, with the earliest known kind being a chariot from Mesopotamia going back to 1900 BC. In addition, a dig uncovered a novel kind of chain suspension as well as leather straps. The gadget, on the other hand, is believed to have been used in the first century BC in Rome. Truck décorating evolved from the ancient idea of cart décoration, which dates back to the 1900s, most likely about 1920, to replace earlier means of transporttation/carriages, such as carts, horses, and litters, which were less decorated with artistic designs than royal carts (Elias, 2003b).

Despite the fact that Pakistan, India, and Bangladesh were unified in 1947 to form the Indian subcontinent, the three republics are still considered distinct states and countries today. The Indian subcontinent has a mythology that spans over 5,000 years and encompasses 1.5 million square miles due to its historical cultural variety. Mountains, farms, timberlands, deserts, lakes, slopes, and streams, as well as a vast variety of temperatures and seasons, are among the natural and physical wonders of the subcontinent, according to Swarp. This organic splendor has a major impact on the local people's culture and way of life. Despite the fact that invasions from other countries brought new people, ideas, thoughts, and acclimatization to the region, the natives' cultural impact has shifted. The division of the Indian subcontinent, on the other hand, had an effect on people's lives, rituals, customs, and traditions. Because both countries' ancestors came from the same land, there was a blending and overlapping of cultural terms and elements that manifested themselves visually in a variety of visual forms, including paintings, clothing, folklore, mythological significance, and various traditions and cultural values. Due to the same geo-graphical circle, the Indo-Pak subcontinent's cultural values were identical, with the exception of religion and religious components (Freitag, 1996). The phulkari stitch, phool buta (floral patterns), and pea-cock motifs are examples of Indian art, crafts, and themes utilized to adorn various surfaces and the aesthetics of Pakistani truck art.

The trucks' design symbolizes the convergence of various ideas and motifs that developed throughout India's colonial period, as well as the uniformity of many art genres. These repetitions provide a new perspective on truck art's attractiveness. Bengal school of painting, post-Mughal fresco art, Swadeshi and Shantiniketan movement philosophy, Calcutta's Kalighat painting styles, and the startling resemblance in ornamental patterns of folk painting with decorative imagery collected throughout India's colonial era Similarly, the appeal of truck art comes from its capacity to develop through time, since it allows for the study of a wide range of styles and themes, as well as the testing of new creative concepts Freitag, 1996). The patterns aren't only seen in Indo Pak art. Arabesque, mythological creatures, Baroque and Rococo decorations, and Romanticism animal depictions are all examples of Islamic geometrical and floral art.

\section{DISCUSSION:}

The Shifting of the Truck Industry to Pakistan and the Rise of Political Visuals (1970). According to Elias' book "On Wings of Diesel," the truck art decorating business migrated from Afghanistan to Pakistan in the 1970s and became known in Pakistan as a social, religious, and political symbol owing to its complex design development and connection. The main reason of the shift in the truck industry is the Soviet Invasion, a civil war in Afghanistan that not only destroyed the country's economy but also had a substantial impact on the Afghan people's social lives (Elias, 2003b). Afghanistan has been a Muslim nation that has prospered in a number of areas since its independence from the United Kingdom in 1919.This faraway country is defined by its beautiful landscape, hills, deserts, flowing rivers, and green crops, as well as its rich cultural history, social structure, customs, and laws. In 1970, Afghanistan 
was a moderate Islamic state capable of embracing culture; the word "pardah" had not yet been used. Despite the fact that Afghanistan had neither road nor railroads in the nineteenth and twentieth century's, several other countries built railway lines for it.

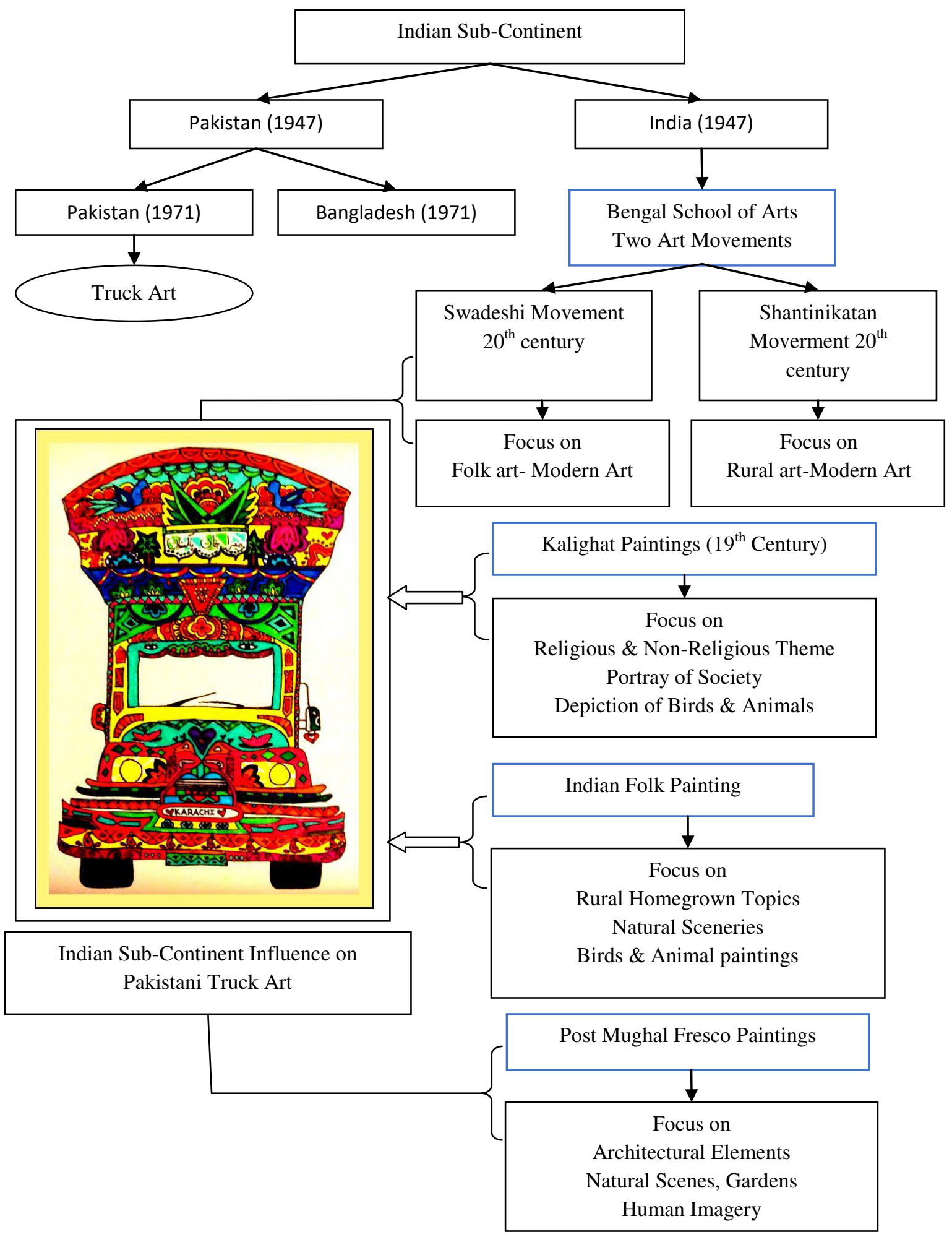

Fig 1: Influences of Indian subcontinent art forms of Pakistani Truck Art.

Furthermore, the borders of the Soviet Union and the Russian Empire impacted the architectural landscape in northern Afghanistan. Agricultural pro-ducts were the main export commodities, and verdant fields and valleys were equally important. Truckloads of fresh UniversePG I www.universepg.com and dried fruits are carried to Pakistan and Iran, owing to brightly coloured trucks with beautiful vistas. Furthermore, the Soviet Union and Afghanistan enjoyed great relations since Afghanistan was the first nation following the Bolshevik revolution to 
recognise the Soviet Communist government, but the Soviet Union invaded Afghanistan for political reasons in 1978. As a consequence, the Mujhahideen fought the Soviets despite the fact that Afghanistan had a population of 17 million people at the time, the most of whom lived in rural regions, while Pakistan and Iran had established refugee camps for 5.5 million people.

The Soviet Union was decommissioned and dissolved in 1989, and the label of "Superpower" was taken away from them. According to Stenning, it's more about destroying cultural heritage than it is about inflicting physical damage. As a consequence, truck art has long been seen as a reflection of current events and circumstances. Political and religious themes started to prevail in cars between 1970 and 1990, confirming this hypothesis. General Mohammad Zia ul-Haq, on the other hand, a Pakistani politician and army commander who lead the Islamic Republic of Pakistan from 1978 to 1988. In his region, he focused on creating Islamic institutions and practises, ushering in an era of "Islamisation." The president's image was painted by truck painters to express their love and support for him as a leader. As a show of their love and respect for him, many truck painters continue to paint his image on the backs of trucks. In 1988, the president's plane accident had an effect on the country's vehicle themes, and the truck's political importance started. In the same year, 1988, Pakistan became an atomic power, prompting truck painters to paint portraits of Prime Minister Nawaz Sharif to show their admiration, support, and love for him. As a consequence of the political environment, the political effect on trucks grew until 1990 (Afghanistan Soviet Invasion, Pakistani President's Air Crash, and Atomic Power).

\section{The Ascension of Religious Visuals}

General Muhammad Zia ul Haq (August 12, 1924August 17, 1988) was the most religiously motivated person on the trucks.

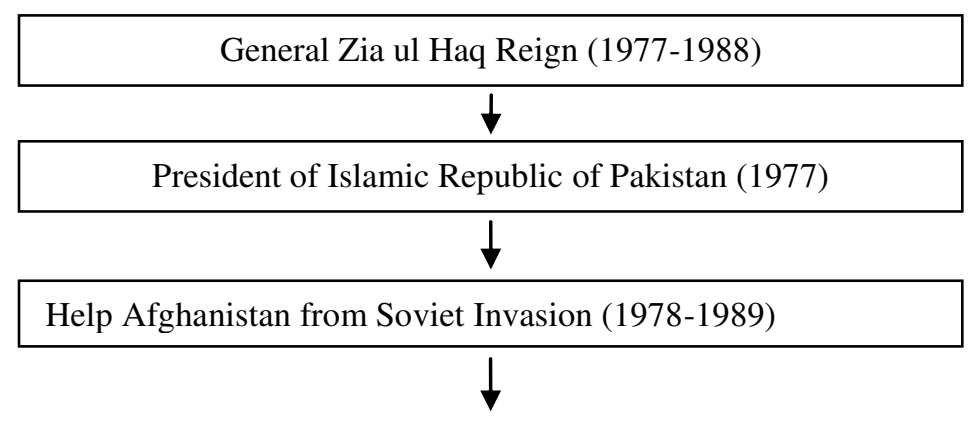

Introduce Islamization, Sharization (1979), was represented as the religious domain on the Pakistani trucks

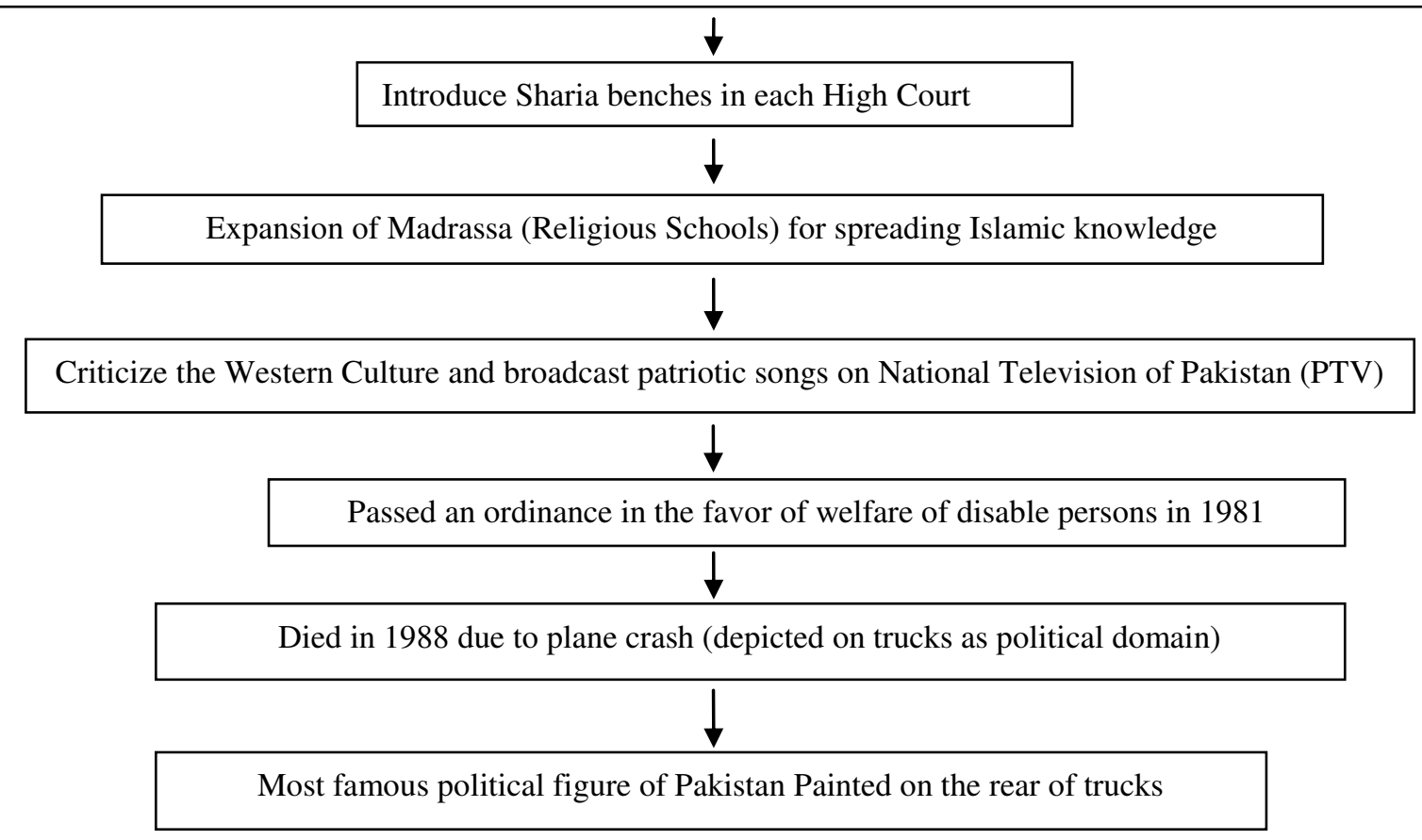

Fig 2: Rationale of political and religious visual rise. 
He was renowned for his humanitarian initiatives as President of the Islamic Republic of Pakistan. He governed for eleven years, the longest period in Pakistan's history (1977-1988) (Jamal Shah, 2012). He implemented a number of changes to turn the nation into a pure Islamic state, including instituting Islamic teachings in the courts, and ushered in the Islamization phase begun by Zulfikar Ali Bhutto. The following are some of the major projects he spearheaded during his presidency (Mehdi, 2013).

'Sharization,' or 'Islamization,' was the emphasis during General Zia ul Haq's reign. In 1977, Prime Minister Bhutto took the first move toward Islamisation by prohibiting western cultural influences such as alcohol and nightclubs. General Zia implemented the Nizam-e-Mustafa, or Islamic System, which included the development of an Islamic state as well as the implementation of Sharia law (Mehdi, 2013). In his inauguration president speech of the Islamic Republic of Pakistan, General Zia stated, "Pakistan, which was created in the name of Islam, would continue to exist only if it attaches itself to Islam." As a consequence, implementing an Islamic system is seen as a need (Kaushik, 1993). Zia created "Sharia Benches" in every High Court to rule on Islamic law in line with the Qur'an and the Prophet PBUH's Sunnah. He did, however, recognize the authority and influence of the Ulama and Islamic political parties. The Islamic Ideology Council now includes ulama (Islamic experts). In a 1979 interview with British journalist Ian Stephens, General Zia justified his actions (Jamal Shah, 2012). "Pakistan was founded on Islam, and Muslims in the subcontinent have their own culture. On the basis of the Two-Nation Theory, this part of the Subcontinent was carved off as Pakistan... Mr. Bhutto prospered in this system by putting students against teachers, children against their parents, landlords against tenants, and mill workers against mill owners (Cheema, 2012). Pakistanis have been persuaded that they may earn money without working, which has led to economic difficulties. Rather than being a choice, we are returning to Islam out of need. My government or I are not forced to follow Islam. The anti-Bhutto street violence reflected the views of 99 percent of the population" (Mehdi, 2013). Many people were opposed to Zia's restrictions as well as the Islamization attempts that were taking place at the time. According to Pakistan's previous First Lady, Nusrat Bhutto: "The horrors of the 1971 war are (still) alive and vivid in the hearts and minds of the people of [Pakistan]." As a consequence, General Zia turned to Islam to ensure the survival of his regime." The development of Islamic schools was also lauded by the public as a fine example of social service (madrassa). During the Zia political period, the religious school received government backing for the first time, enabling it to expand. Despite this, the total number of madrassas increased from 893 to 2,801 under his reign. The Zakat councils backed it up, and it provided free religious education, housing, and food to Pakistanis (Jamal Shah, 2012). He focused not just on the social elements of society, but also on its cultural policies. Zia blasted the country's growing Western culture and music in his inaugural address to the nation in 1979. Patriotic anthems were first broadcast on PTV, Pakistan's national television, after substantial support from the world's most powerful country, the United States, and amicable discussions between Zia and President Ronald Reagan. According to cultural historian Nadeem F. Paracha, in 1980, economic prosperity grew, and the western fashion industry grew in importance (Cheema, 2012). During General Zia's administration, he prioritised the welfare of disabled people and passed legislation to that effect. The 'Disabled Persons (Employment and Rehabilitation) Ordinance, 1981' was signed into law on December 29, 1981. It was the first time a resolution in favour of the handicapped population was passed, and it addressed problems like employment, rehabilitation, and social support for impaired people. As a consequence of his Islamization drive, both Zia's image and the Fundamentalist Party's political prospects increased. Following the Soviet invasion of Afghanistan, the United States reawakened its strategic interests in the area by giving Pakistan with a $\$ 3.2$ billion package of economic and military assistance. During the conflict, Zia helped transport US weapons to Afghan insurgents backed by the Soviet Union, allowing them to set up training camps in Pakistan. Three million Afghan refugees were given asylum by General Zia of Pakistan, a neighboring Muslim country (Mehdi, 2013).

On August 17, 1988, Zia, US Ambassador Arnold Raphel, US military troops, and 27 Pakistani advisers embarked on a covert mission to a desert region in eastern Pakistan, where Zia and Raphel boarded a C-130 aircraft bound for Islamabad. The plane exploded minutes after takeoff, killing every- 
one on board. Despite the appearance of a suspicious explosion, Pakistani and American investigators were unable to determine where the bomb originated. Experts believe it has something to do with General Zia's foes (Jamal Shah, 2012). Despite the involvement of the Soviet Union, the Indian government, Bhutto's People's Party, and Zia's own military, no evidence was ever found. In November 1988, Benazir Bhutto, the daughter of a politician assassinated by Zia, became Pakistan's first female Prime Minister (Mehdi, 2013).

\section{Pakistani truck art has been dubbed the "Arena of Contest" and "Popular Art" in Pakistan}

Schmid refers to truck art as a kind of popular culture, describing it as a "arena of contest." On the other hand, popular culture is characterised by massproduced images that change appearance over time, emerge and vanish, or are filmed in a certain way. In the same way, today's popular culture is focused on making connections, recognising and perceiving things, and being entertained or distracted. This truck art essay is widely regarded as one of the finest in the industry (Schmid, 2000). Truck art is explored within the backdrop of popular culture, emphasising social connections, behaviours, and creative approaches to the art form. Using a range of interpretative techniques, she looked at the messages conveyed by the truck's drivers, artists, and the general public throughout her study (Kirkpatrick, 2012). According to her, those who worked on truck art, such as painters and craftsmen, were proud of their skills and personal innovations, as well as their knowledge and creative abilities exhibited via the many methods and materials they employed. She said that rather than analysing patterns and symbols, the surrounding environment gives information about the vehicle in context. On the other hand, Wolfgang Schnotz believes that images/picturization is the most effective ways for grasping knowledge in more detail. Because truck art is associated with a variety of societal settings, Schmid portrayed the three worlds of this art form: cultural, political, and religious, in order to demonstrate how it mirrors popular culture. Another interesting aspect she discussed in her piece was the art form's constant experimentation. The paintings on the trucks were first simply allusions to political symbols and national problems, particularly after Pakistan's nuclear power programme was shut down (Schmid, 2000). To show their gratitude, the bulk of the trucks had images of the Prime Minister on them, but today they are adorned with paintings of different themes related to society and religion. Painters, according to Schmid, are always looking for creative frameworks that include what they believe are needed to affect change via their medium. The availability of new ideas via invention and dissemination is related to change and adaptation. In any case, this adaptability/flexibility method does not explain why a concept gets accepted. Adoption, or a survival system, is a potentially useful notion for social geography in terms of variety and its origins, the process of selection among variations, and either change or the ability to resist natural change. Similarly, it makes little difference to truck painters whether the subject is from a foreign or domestic environment. The sole need for a theme's success is that it may be adapted into a national setting or iconographic style, such as a Swiss scene, colourful feathered animals that created the planet, and so on. Sheikh has under-taken another study to demonstrate the effect of truck art as popular culture, this time inspired by Schmid's phrase. As previously mentioned, Schmid utilised the interpretative device as a method to link the art form to popular culture via the comments of truck owners, drivers, and the general public. Sheikh's study, on the other hand, is focused on deciphering common metaphors that have allegoric, symbolic, historical, or current meaning depending on how they were conveyed via images (Sheikh, 2018).

The need of integrating art and crafts into heavy vehicle decoration and adornment is stressed, which Elias and Schmid investigated in many ways. Truck art, like pop culture, is an effort to delve deeper into the meaning of images (metaphors) that are widely seen. According to Sheik, truck art is a powerful mode of articulation of metaphoric under-standings that allows one to become an analyst with the most fascinating investigation of cultural beliefs, taboos, traditions, and values, as well as regularly communicate messages through skilfully used epigraphy and elucidations that leave a lasting impression, making it more enjoyable than its aesthetic value (Kirkpatrick, 2012). Sheikh offers nine metaphoric design forms, although other academics have proposed a different number of categories (Sheikh, 2018). Sheik went on to say that truck art is considered poor art by academic art organisations. It is, nevertheless, a reliable method of communication both inside and across cultures. She supported her argument by 
stating that there are two kinds of art: one for the higher class and the other for the lower class. Art is assessed on aesthetic criteria in order to determine its position and competency, while it was formerly exclusively concerned with social problems (Sheikh, 2018).

The following topics, on the other hand, have grown in popularity, and they are currently being created in cultures and subjects concerned with conveying everyday problems. Truck art is similar in that it contains a broad variety of concepts, tales, and metaphors in addition to reflecting the communities to which it belongs. Another noteworthy work on the topic is Marie Benedicte Dutreux's doctorate dissertation on Afghan and Pakistani truck art, which she finished in 1978 in Paris. Truck art became popular in Pakistan's western neighbour, Afghanistan, at first. As a consequence of the Soviet invasion and subsequent civil war in Afghanistan, this art style spread to Pakistan from 1978 to 1989. It eventually acquired popularity as a cultural portrayal of Pakistan. Truck art became popular in Afghanistan about 1970 as a consequence of commodities trade, according to Elias' book "On Wings of Diesel." Marie Benedicte's dissertation was the first to concentrate on truck art designs and photographs, but it was halted owing to faults in the evaluation when she converted/translated the native language inscribed on the trucks to a foreign one. As previously said, trucks come from all over the globe, and each region has its own language, which is inscribed on the truck from that location as one of the distinguishing features of truck art (Schmid, 2000). Because truck art is a cultural manifestation of a country's art and culture, it is best described by the local enhanced language of that region. According to Elias, Marie Benedicte's dissertation was a failure as a result." The dictionary is founded on the hypothesis - an untested hypothesis - that languages are made up of similar synonyms," Jorge Luis Borges says in this respect. Jurgen Grothues produced a graphic book on truck art in 1990. The significance of truck art as visual iconography was emphasised in this picture book, which included a variety of styles and layouts(Sheikh, 2018).

According to Catherine, visual imagery creation is a mental disorder. It entails duplicating what we perceive. It does, however, enable us to communicate our emotions about what we're experiencing.

\section{Truck art as "Panoramic Art" and "Synthetic} Art"

Sökefeld used the term "synthetic art" to describe Pakistani truck art since it included a broad range of artist studies that looked at the cooperation of the artists. Sökefeld split the vehicle into three parts for his study, concentrating on truck workshops and truck components including the front, back, and sides (Sökefeld, 2008). Sokefeld went into great detail about the adda, which is made up of a variety of workshops that specialise in different fields. Lohar (weld the metal adornments) and Badimeker (the wooden body, the cargo compartment of the trucks) and Badimeker (chip away at the engine) (paint the trimmings and pictures near the conclusion of the process). Likhaiwale is a term used to describe small groups of three or four men who collaborate on a project (cover photograph). An ustad is in charge of the group. Apart from him, one professional painted the paintings, while non-specialists painted the decorations and other non-figurative elements of the décor. Sökefeld scrutinised every painted detail. Many of the parts were pre-fabricated out of coloured plastic or reflective tape (Sökefeld, 2008).

There were many little businesses surround-ing the adda that manufactured and sold these plastic and tape items. As previously stated, Elias offered five vehicle types, while Sökefeld presented three after compiling data from the interviews. According to him, Rawalpindi's likhaiwale were split into two different genres in the mid-1990s: disco and sada (simple). Pind (the usual short form of Rawalpindi), Havelian (also known as Mansehra or Abbottabad), and Peshawari (all three main cities were located in the Hazara area of the NorthWest Frontier Province) are the three different variants presently recognised (this being named after the capital of the region). The scale and proportions of allegorical/figurative paintings in various genres vary dramatically(Elias, 2003b). The two professions were combined since the Pindi style is comparable to traditional disco gari. Sada gari in the traditional style was similar to Havelian style. A single column of allegorical/ figurative artistic works flanks the vehicle organization's name, which is prominently printed in big letters on the flanks. These basic components were surrounded by a few adornments, as opposed to a disco gari, where the majority of the surface is undecorated. Furthermore, in the Havelian style, human 
images are never utilised. The fashion in Peshawari is regarded to be moderate. The original artworks on the sides of the truck have been scaled down and embellished. They're in the middle of the sides, held in place by elaborate embellishments above and below. Furthermore, human pictures are never utilised in the Peshawari style. In truck art, Havelian and, in especially, Peshawari styles exhibit traces of Islamization (Sökefeld, 2008). The South Asian Deobandi School and the Saudi-Arabia Wahhabism School have acquired considerable footing and influence in Pakistan, particularly in the North-West Frontier Province, since General Zia ul Haq backed a legislative push for Islamisation in the late 1970s. Truck art may be viewed as a confrontation between Islamic universality and pop culture, with its exquisite moderation of the Peshawari style on the one hand, and the expanded richness of the Pindi style on the other, which included the fame of images of exposed women. The artwork on the back of the truck is referred to as "panoramic art." It is often used as a mural or panoramic art since it is the biggest area in the rear of the vehicle. The aesthetic viewpoint or dimensions of vehicles, according to Sokefeld, may be split into three components (Sökefeld, 2008). The front, back, and sides of the vehicle were also labelled by Elias. Elias categorised the four trucks as Shia, Sunni, or Tabligi trucks based on the arrangement of design components on the vehicle. In her essay "The Truck Art of Pak-istan," Chappell Ellison looked into the history of Pakistani truck art, saying that the country's truck art is now recognised throughout the globe. Clothing influenced by Pakistani truck art has been created by several well-known Indian designers, including Deepak Parwani and Manish Arora. Chappell created the phrase "Pakistani truck art" to describe a culture that thrives on the streets. "Truck Art and Poetry: A Story in Motion," by Aisha Asim Imdad, was released in 2016. The impact and adaptability of shifting culture are examined in this THAAP journal article (Indo-Pak Subcontinent) (Imdad, 2018).

According to Aisha Asim, Indian Subcontinent culture, especially Indian Kalighat paintings, has inspired Pakistani truck art. Not just in Pakistan, but also in India, especially in Bengal, truck art is practised. The 'Bengal School of Arts' honours the art form's uniqueness while also serving as a source of inspiration for future artistic endeavours."The storey of Kalighat painting is the storey of the UniversePG I www.universepg.com transition of a traditional art form into a popular genre," explains Brahma Jyotindra Jain (Sanyal, 2013). It included new British immigrant habits and traditions, revivalist Mughal court culture, and Sanskrit drama on a proscenium stage. Kalighat art became urban, free, innovative, and liberal as a result of these varied cultural conditions. According to the author, fresco paintings have inspired truck art. She feels that Pakistani truck art is unique in terms of look and characteristics because of the culture and history of Pakistani society, which she believes is represented in the complex design patterns and components of their trucks. The trucks' most attractive feature is that they have maintained their historical origins, which contributes to the development's charm (Imdad, 2018). In addition to these books, journals, and articles, there is a wealth of material about truck art available via blogs, magazine articles, and newspaper columns. In 2008, Ali Usman published an essay titled "Pakistan's truck art" in journals and publications such as the New Daily Times, in which he explored the geographical importance of truck art, as well as its history and themes, with a focus on interview answers from truck drivers and artists. Other articles about truck art, such as Kurt's "Art on Wheels; Pakistan's Magnificent Truck Art," George Rich and Shahid Khan's " The aesthetic and organisation of an artisan trade," and Salwat Ali's "Desi by Designs," all published in Dawn, a Sunday magazine, are shown below, as well as a coffee table discussion about truck art, its features, and significance.

\section{Religious Metaphoric Significance of Truck Art}

"Spiritual space" and "religious imagination" are Elias' primary terms for conveying his thoughts on Pakistani truck art. He focused on two elements of truck art in his works: the history of vehicle decoration as a major popular art form and the nature of popular Islamic culture's responses to religious imagery (Kirkpatrick, 2012). The Karakorum High-way, Karachi's business sector, Rawalpindi and Islamabad, and the Karakorum Highway were the focus of his research in Pakistan's northern and southern areas. Extensive interviews with vehicle owners and artisans were conducted as a tool. Following the data gathering, Elias proposed five regional kinds of truck art in terms of organization and appearance: Punjabi, Swati, Peshawari, Baluchi, and Karachi styles. The Punjabi style is considerably more elaborate, with metal cowlings, hammer work, and plastic appliqué 
work done with a variety of brilliantly bright adhesives, according to Elias (Elias, 2005). Swati architecture is distinguished by its plainly carved wooden doors with little decoration. The Peshawari style lies between the Punjabi and Swati styles due to the usage of metal cowling and decoration on the wood carvings. Baluchi art is geometrical and has sparsely drawn portraits, which aided him in his studies. Finally, the botanical and floral motifs carved onto the wooden panel above the windscreen distinguish the Karachi design (Elias, 2003a). Furthermore, his research showed six differ-rent design concepts, while Sheikh proposed nine. Talismanic and fetish objects, as well as talismanically and religiously loaded images, were categorized as such, while Islamic icons, imageries, and calligraphies were classified as explicit religious symbols and pictures. Photographs of aircraft, celebrities, singers, politicians, and sports are considered modern, while realistic paintings of majestic snow-capped mountains, landscapes, rural views, birds, and animals are considered idealized elements of life. The nonreligious calligraphic programme includes all of the clever, humorous, and couplets of songs (Sheikh, 2018). Elias' 'On Wings of Diesel,' released at the turn of the twenty-first century, is the sole book on the significance of truck art. The book portrays the holy world of trucks in a beautiful way while also giving historical back-ground for Pakistani truck art (Elias, 2003b). Mullahs, or religious authorities, began a political campaign against the use of human pictures on cars in the early 1980s. During the era of Islamisation, when human imageries were considered gunnah or evil deed by Elias, the frontal portion of the truck is decorated with purely religious images, with different layouts at different areas, and so the frontal portion of the truck is decorated with purely religious images, with differ-ent layouts at different areas. The contents and concepts of the book have been carefully researched, and the visual depiction of religious symbols has been praised. In a nutshell, the book provides a comprehensive examination of truck art, as well as a catalogue of all religious elements found in the images.

In 2005, Elias delved further into the trucks, seeing them as material culture and acknowledging the social significance of their religious identities. The debate centered on the religious identity associated with truck painting culture, as well as the impacts and perspectives that vehicle aesthetics have on UniversePG I www.universepg.com
Pakistani religious components (Hawladar and Fakaruddin, 2021). Four vehicles were examined in his research as evidence of his claim that three of them possessed religious qualities, with the fourth, the Tablighi jamaat, serving as a decorative statement (Kirkpatrick, 2012). According to Elias, the aim of religious imagery is "apotropaic or talismanic." Apotropaic painting and adorning on trucks with a significant religious meaning were believed to protect the vehicle, its cargo, the truck owner, and the drivers, as well as bring them good fortune, he added (Elias, 2005). He also observed that certain ornamental features seemed to be religious in character but did not appear to have any apostrophic purpose. Those connected to the truck, according to Elias, used the art form as a social badge enabling them to be recognized and represented in society (Elias, 2003a).

\section{Suggestions for the Future}

As the previous debate demonstrates, the majority of scholars are focused on different perspectives on truck art. Religious Domain, Political Domain, and Cultural Domain are the three realms of religious, political, and cultural orientations. Scholars examine and study the Islamization of truck art, giving a thorough examination of the spiritual effect and religious appearance of truck art from many viewpoints. For example, Ustaad, Badimakerz, and Likahi Walay concentrate on depicting truck art workshops and groups of artists and artisans engaged in décorating and constructing. We may detect a gap, such as a lack of data on the importance of truck art visual explanation, since prior studies have mainly focused on specific effects.

\section{CONCLUSION:}

The partition of the Indian subcontinent, (1947), the division of Pakistan's East and West, General Zia ul Haq's Islamization, and the civil war in Afghanistan after the Soviet invasion are all covered in this article. As evidenced by a series of supporting documentation and other relevant publications with references to truck art as the initial representative of the themes and calligraphic texts associated with religion, the majority of the influence and themes associated with truck art are clearly seen in this chapter to represent the religious and political do-mains. As a consequence of important political events that occurred towards the end of the twentieth century, religion played a significant role in politics and had a significant effect on the country's environment. The 
cultural context of the trucks metaphoric design features, themes, and subject themes, on the other hand, got just a beneficial for high.

\section{ACKNOWLEDGEMENT:}

First and foremost, I would like to thank God Almighty for giving me the strength, knowledge, ability and opportunity to undertake this research study and to persevere and complete it satisfactorily. I would like to acknowledge my indebtedness and render my warmest thanks to my supervisor, parents and siblings who made this work possible. Their friendly guidance and expert advice have been invaluable throughout all stages of the work. They always being there at times when I required motivation and propelling me on the course of this thesis and also for assisting me in different phases for my research. Their support, encouragement and credible ideas have been great contributors in the completion of the research.

\section{CONFLICTS OF INTEREST:}

The author declares there is no conflict of interest to publish it.

\section{REFERRENCES:}

1) Cheema, M. (2012). 'Beyond Beliefs: Deconstructing the Dominant Narratives of the Islamization of Pakistan's Law', American Journal of Comparative Law, 60(4), pp. 875917. https://doi.org/10.5131/ajcl.2012.0008

2) Elias, J. J. (2003a). 'Spiritual space and religious imagination in Pakistani truck decoration', Res: Anthrop. and Aesthet, pp. 187-202. https://doi.org/10.1086/RESv43n1ms20167598

3) Elias, J. J. (2003b). 'Spiritual space and religious imagination in Pakistani truck decoration', Res: Anthropology and Aesthetics. Peabody Mus. of Arch. and Ethn, pp. 187-202. https://doi.org/10.1086/RESv43n1ms2016 7598

4) Elias, J. J. (2005). 'Truck decoration and religious identity: Material culture and social function in Pakistan', Material Religion. Bloomsbury Publishing Plc., 1(1), pp. 48-70. https://doi.org/ 10.2752/174322005778054456

5) Freitag, S. (1996). 'Making of a New 'Indian'
Art: Artists, Aesthetics and Nationalism in Bengal, c. 1850-1920. By Tapati Guha-Tha-kurta. Cambridge: Cambridge University Press, 1992.

6) Hawladar M, and Fakaruddin M. (2021). Indian paintings: an analysis of geographical and chronological context, Asian J. Soc. Sci. Leg. Stud., 3(3), 75-84.

https://doi.org/10.34104/ajssls.021.075084

7) Imdad, A. (2018). Truck art and poetry. https://scholar.google.com/scholar?hl=en\&as sdt $=0 \% 2 \mathrm{C} 5 \& \mathrm{q}=$ aisha + imdad + truck + art \&btnG

8) Jamal Shah, (2012). Zia-Ul-Haque and the Proliferation of Religion in Pakistan, International J. of Bussiness and Social Science. https://kewd.pw/fu_firu.pdf

9) Kaushik, S. N. (1993). Politics of Islam-ization in Pakistan: A study of Zia regime. http://121.52.159.154:8080/jspui/bitstream/12345 6789/293/1/Islamization in Pakistan.pdf

10) Kirkpatrick, J. (2012). 'On Wings of Diesel: Trucks, Identity and Culture in Pakistan. By Jamal J. Elias. Oxford, England: Oneworld Publications, 2011. xv, 252 pp. $\$ 45.00$ (paper).' The J. of Asian Studies, 71(1), pp. 287-288. https://doi.org/10.1017/s0021911811002828

11) Mehdi, R. (2013). The islamization of the law in Pakistan (RLE Politics of Islam), Routledge, Taylor and Francis; pp. 344.

https://doi.org/doi: 10.4324/9780203381298

12) Sanyal, P. (2013). 'Kalighat Paintings: A review', books.google.com.

13) Schmid, A. (2000). 'Truck Art as Arena of Contest', J. of Soc. Sciences. 4(4), pp. 235-241 https://doi.org/10.1080/09718923.2000.11892273

14) Sheikh, S. Z. (2018). 'Impact of truck art, as popular culture on Pakistani society', International J. of Multi-disc, and Current Research, 6(5). https://doi.org/10.14741/ijmcr/v.6.5.10

15) Sökefeld, M. (2008). 'Moving images', epub.ub.uni-muenchen.de. Available at: https://epub.ub.uni-muenchen.de/13150/1/soek efeld 13150.pdf

Citation: Zahra F. (2021). Truck art in retrospect: the ascension of religious, political and cultural visuals, Br. J. Arts Humanit., 3(5), 106-115. https://doi.org/10.34104/bjah.02101060115 @ @ 